\title{
Assessment of Radical Scavenging and Sickling Inhibitory Activities of the Bark of Disthemonanthus Benthamianus (Caesalpiniaceae)
}

\author{
Akakpo-Akue Joël (Doctor) \\ Ahon Gnamien Marcel (Doctor)
}

Laboratory of Biology and Health, UFR Biosciences, University Félix

Houphouët-Boigny (UFHB), Côte d'Ivoire

Kplé Tatiana Kangah Mireille (PhD Student)

Laboratory of Biology and Health, UFR Biosciences, University Félix

Houphouët-Boigny (UFHB), Côte d'Ivoire

Immunity Biology Center, Institute Pasteur of Côte d'Ivoire, Côte d'Ivoire

Fofié Yvette (Professor)

Pharmacognosy Laboratory, UFR of Pharmaceutical and Biological

Sciences, University Félix Houphouët-Boigny, Côte d'Ivoire

Ibrahime Sanogo (Professor)

Clinical Haematology Department,

University Hospital of Yopougon, Abidjan, Côte d'Ivoire

Yapo-Crezoit Antoinette Claire Chiyae (Professor)

Immunity Biology Center, Institute Pasteur of Côte d'Ivoire, Côte d'Ivoire

Kra Adou Koffi Mathieu (Professor)

Laboratory of Biology and Health, UFR Biosciences,

Université Félix Houphouët-Boigny (UFHB), Côte d'Ivoire

Doi:10.19044/esj.2021.v17n10p121

Submitted: 30 November 2020

Accepted: 18 January 2021

Published: 31 March 2021
Copyright 2021 Author(s)

Under Creative Commons BY-NC-ND

4.0 OPEN ACCESS

Cite As:

Akakpo-Akue J., Ahon Gnamien M., Kplé Tatiana K.M., Fofié Y., Ibrahime S., Yapo-Crezoit A.C.C. \& Kra Adou K.M. (2021). Cuarentena por COVID-19, factor asociado al consumo de drogas legales en estudiantes de enfermería. European Scientific Journal, ESJ, 17(10), 121. https://doi.org/10.19044/esj.2021.v17n10p121

\section{Abstract}

Among the medicinal plants used in the treatment of sickle cell disease in south-east of Côte d'Ivoire is Disthemonanthus benthamianus. This paper focuses on assessing its antioxidant properties and its antisickling activity. The 
test of inhibition of sodium metabisulfite-induced sickling of the erythrocytes was carried out based on this evaluation. The total phenolic compounds contents were $45 \pm 0.64$ and $39.84 \pm 0.69 \mathrm{mg} / \mathrm{g}$ of dry weight for ethanolic extract and the decocted respectively. The DPPH reduction test showed that the decocted $(9 \mu \mathrm{g} / \mathrm{mL})$ had a lower $\mathrm{IC}_{50}$ than the ethanolic extract $(16 \mu \mathrm{g} / \mathrm{mL})$. There was no significant difference between the sickling inhibitory activities of the ethanolic extract (87.00\%) and the decocted (81.66\%). This study showed that both extracts had sickling inhibitory and antioxidant activities.

Keywords: Disthemonanthus benthamianus, phenolic compounds, antioxidant activity, antisickling activity, Côte d'Ivoire

\section{Introduction}

The use of medicinal plants in therapeutics throughout the world is currently experiencing an interest among the population despite the progress of modern medicine. More than $80 \%$ of the world population use medicinal plants to cope with health problems (WHO, 2008). One of the reasons is that many diseases are treated successfully by plants (Kamanyi et al., 1995). Indeed, plants are source of natural bioactive molecules with antiinflammatory (Gonzalez et al., 2011), antimicrobial (Daglia, 2012), antiviral (Chavez et al., 2006), antisickling (Sawadogo et al., 2017; Kitadi et al., 2015; Akakpo et al., 2018), and antioxidant (Pandey \& Rizvi, 2009; Diomandé et $a l ., 2018$ ) properties. The cost of patient care is not always affordable for lowincome populations. Therefore, many Ivorian people use medicinal plants to treat several ailments even chronic diseases such as sickle cell anemia (Béné et al., 2016). Sickle cell disease or sickle cell anemia is a genetic disorder with autosomal recessive transmission. It results from the substitution of glutamic acid in position 6 by valine, affecting the 6 th codon of the $\beta$-globin chain. In deoxygenated red blood cells, hydrophobic valine, unlike glutamic acid, causes a change in hemoglobin conformation that leads to its polymerization and to the sickle-formation (Chiabi \& Haenggeli, 2004). The polymerized hemoglobin could undergo self-oxidizing, thereby inducing the formation of methemoglobin by the oxidation of $\mathrm{Fe}^{2+}$ to $\mathrm{Fe}^{3+}$. The auto-oxidation of hemoglobin generates free radicals (Hebbel et al., 1988). Sickle cells and oxidative stress are important characteristics of the disease and play a major role in the process of hemolytic anemia, vaso-occlusion, and organs damage which are the major clinical signs of sickle cell patients (Nur et al., 2011). Given the diversity and severity of diseases induced by oxidative stress, various research teams have investigated new antioxidants compounds. In view of the oxidative stress presence in sickle cell disease, new plant sources of natural antioxidants are now being sought (Arruda et al., 2013). In this work, we reported the results of the assessment of the in vitro antioxidant and 
sickling inhibitory activities of the decocted and ethanolic extract of Disthemonanthus benthamianus bark.

\section{Materials and Methods}

\section{Harvesting and Conditioning Plant Material}

The plant material consisted of Disthemonanthus benthamianus stem bark. It was harvested from Indenié-Djouablin $\left(6^{\circ} 43^{\prime} 47^{\prime \prime}\right.$ North and $3^{\circ} 29^{\prime}$ 47" West), a region in eastern Côte d'Ivoire. The plant identification has been done at the National Floristic Center with the specimen number of 12473. The stem bark has been washed, cut, and then air dried at room temperature $\left(25^{\circ} \mathrm{C}\right)$ in Biology and Health laboratory at the biosciences UFR of Félix HouphouetBoigny University. After three weeks of drying, then the bark was grounded into powder using a Severin ${ }^{\circledR}$ brand grinder.

\section{Disthemonanthus Benthamianus Stem Bark Extraction}

Ethanolic Extract (EDB) Preparation: Hydroethanolic extract has been produced according to the protocol of (Zirihi et al., 2003). One hundred grams $(100 \mathrm{~g})$ of the ground plant were soaked in one liter of hydroethanolic $70 \%$ solution. The mixture was homogenized 10 times for 2 minutes each time using a Severin ${ }^{\circledR}$ brand blender. The obtained homogenate was wrung out using a square of white cotton fabric and then filtered successively three times on hydrophilic cotton and once on Whatman paper $(3 \mathrm{~mm})$. The filtrate was evaporated at $45^{\circ} \mathrm{C}$ using a Venticell ${ }^{\circledR}$ oven. The resulting extract was named EDB.

Plant Decoction (DDB): According to the method of Konkon et al. (2008), one hundred grams (100g) of ground plant were brought to a boil for 20 minutes in $2 \mathrm{~L}$ of distilled water, the mixture was cooled at room temperature $\left(25^{\circ} \mathrm{C}\right)$, filtered three times on cotton, and once on Whatman filter paper 3. The resulting filtrate was then dried at $50^{\circ} \mathrm{C}$ in the oven. The dried powder was named DDB.

\section{Antioxidant Properties Evaluation}

Total Polyphenols and flavonoids phytochemical screening were carried out in pharmacognosy laboratory at Pharmaceutical and Biological Sciences UFR of Félix Houphouet-Boigny University.

\section{Determination of Total Phenol Content}

The total phenolic compounds content has been determined using Folin-Ciocalteu assay method (Singleton et al., 1999). One (1) mL of FolinCiocalteu reagent was added to the extract, $1 \mathrm{mg} / \mathrm{mL}$ in a test tube. After 3 minutes, $1 \mathrm{~mL}$ of $20 \%$ sodium carbonate solution (w/v) was added to the test tube and completed to $10 \mathrm{~mL}$ with distilled water. After 30 minutes, the 
absorbance was read at $745 \mathrm{~nm}$ against a methanol blank on a spectrophotometer Jenway 7315. A standard range, based on $0.1 \mathrm{mg} / \mathrm{mL}$ of Gallic acid stock solution, allowed the determination of phenols concentration in the sample. The result was expressed in $\mathrm{mg} \mathrm{GAE} / \mathrm{g}$.

\section{Determination of Flavonoids Content}

The total flavonoid content was determined from the calibration curve made of $0.1 \mathrm{mg} / \mathrm{mL}$ stock solution of Quercetin, using direct quantification by aluminum chloride method (Meda et al., 2005). Zero point $5(0.5) \mathrm{mL}$ of distilled water, $0.5 \mathrm{~mL}$ of aluminum chloride, $0.5 \mathrm{~mL}$ of potassium acetate, and $2 \mathrm{~mL}$ of distilled water were added to $0.5 \mathrm{~mL}$ of EDB or DDB. After 30 minutes, the absorbance was read at $415 \mathrm{~nm}$ against methanol as blank. A standard range established from a $0.1 \mathrm{mg} / \mathrm{mL}$ Quercetin stock solution was used to determine the amount of flavonoids in the EDB or DDB. The result was expressed in $\mathrm{mg} \mathrm{QE} / \mathrm{g}$ :

\section{Free Radical Scavenging Assay}

DPPH (2, 2 diphenyl-1-picrylhydrazyl) is generally the most widely used substrate for rapid and direct assessment of antioxidant activity due to its stability in free radical form and simplicity of analysis. It absorbs in the visible at the wavelength of $517 \mathrm{~nm}$. The experimental protocol used to study DPPH free radical scavenging activity was that described by Parejo et al. (2000) with some slight modifications.

\section{Reducing Power Assay}

The reducing power of plant extracts was carried out as described by Yildirim et al. (2001). It was measured by the increase in the absorbance at $700 \mathrm{~nm}$ of the Perl's Prussian blue due to the $\mathrm{Fe}^{3+} \mathrm{Fe}^{2+}$ transformation.

\section{Qualitative Research of Aromatic Amino Acids}

Aromatic amino acids were sought through the xanthoprotein reaction. To $3 \mathrm{~mL}$ of extract, $1 \mathrm{~mL}$ of concentrated nitric acid was added. The tube was then boiled for 2 minutes. The appearance of a yellow coloration indicates a positive reaction which highlights the presence of aromatic nuclei (benzene ring); amino acids of the aromatic series: tyrosine, tryptophan, and phenylalanine. The test was performed according to Fofana (2004).

\section{Sickling Inhibitory Activity Assessment Collection and Conditioning of Blood Samples}

An agreement was obtained from the ethics committee and an informed consent was approved by each voluntary sickle cell patients selected at Yopougon University Hospital in the Clinical Hematology Department. To 
be included in the study, the blood should come from homozygous sickle cell patients. The voluntary patients shouldn't have undergone blood transfusion for at least two months prior to the blood test, regardless of age and gender.

Venous blood was collected in tube (EDTA). These samples were placed in a cooler and conveyed at $4{ }^{\circ} \mathrm{C}$ to Biology of Immunity Pole of Pasteur Institute of Côte d'Ivoire (IPCI).

Patients who had been transfused before the two months prior to blood collection, homozygous patients with foetal hemoglobin levels greater than $5 \mathrm{~g} / \mathrm{dL}$, and patients in crisis were not considered.

\section{Sickle-Formation Inhibition Test}

The test was performed according to Emmel's method (1933) which was slightly modified (Mpiana et al., 2014). The blood sample was centrifuged for 5 minutes at 3000 rounds/min and the supernatant was removed with a Pasteur pipette. One (1) $\mathrm{mL}$ of the washed red blood cells was suspended in $1 \mathrm{~mL}$ of physiological buffer ( $\mathrm{NaCl} 0.9 \%)$. EDB and DDB solutions of 5 and $10 \mathrm{mg} / \mathrm{mL}$ were prepared with $\mathrm{NaCl} 0.9 \%$. A volume of $50 \mu \mathrm{L}$ was homogenized with $50 \mu \mathrm{L}$ of washed blood in a test tube. A volume of $50 \mu \mathrm{L}$ of sodium meta-bisulfite $(2 \%, \mathrm{w} / \mathrm{v})$ was added to the mixture to create the sickle-formation conditions. The tube was sealed with paraffin. Negative and positive controls were prepared. The negative control was prepared by mixing $50 \mu \mathrm{L}$ of washed blood with $50 \mu \mathrm{L}$ of physiological buffer and $50 \mu \mathrm{L}$ of sodium meta-bisulfite $(2 \%, \mathrm{w} / \mathrm{v})$. The positive control was prepared by mixing $50 \mu \mathrm{L}$ of washed blood with $50 \mu \mathrm{L}$ of a phenylalanine solution at $10 \mathrm{mg} / \mathrm{mL}$ and $50 \mu \mathrm{L}$ of sodium meta-bisulfite $(2 \%, \mathrm{w} / \mathrm{v})$. The tubes were put in dark room for 120 minutes. Erythrocytes morphological analysis and counting of sickle cells were made by an observation X 40 under a microscope. The sickling Inhibitory activity was expressed in percentage of sickle cells formed in the presence of the plant extracts compared to the number of sickle cells present in the negative control. This activity is determined by the formula noted below:

$$
\mathrm{AA}=\frac{\mathrm{Po}-\mathrm{P} 1}{\mathrm{Po}} \times 100
$$

AA: antisickling activity; Po: sickle cells rate in the control; P1: sickle cells rate in plant extract's presence. The experimental results were expressed as means \pm standard error of means (SEM) of three replicates. Where applicable, the data were subjected to one way analysis of variance (ANOVA) and differences between samples were determined by Tukey and Duncan's Multiple Comparison test using Graph Pad Prism 7.0 program. 


\section{Results}

\section{Total Phenolic and Flavonoids Compounds Contents Determination}

The quantitative analysis of EDB and DDB phenolic compounds was determined from the Gallic acid calibration curve, equation $\mathrm{Y}=8.1544 \mathrm{X}$ and $\mathrm{R}^{2}=0.9732$. The total flavonoids were determined from the Quercetin calibration curves, equation $\mathrm{Y}=1.36 \mathrm{x}-0.0181$ and $\mathrm{R}^{2}=0.9976$. The polyphenol concentration of EDB (45.11 $\pm 0.64 \mathrm{mg}$ GAE/g of dry weight) was significantly $(p<0.05)$ higher than that of DDB $(39.54 \pm 0.69 \mathrm{mg}$ GAE /g of dry weight). The total flavonoids content in EDB and DDB follow the same trend as the polyphenols concentration. The content in $\mathrm{EDB}(15.52 \pm 0.25 \mathrm{mg}$ QE/g of dry weight) is higher than that of DDB (15.64 $\pm 1.44 \mathrm{mg} \mathrm{QE} / \mathrm{g}$ of dry weight). The results were reported in Table I.

\section{DPPH Radical Scavenging Activity}

The results obtained during the determination of the different extracts by the DPPH radical were shown in Table I. The $\mathrm{IC}_{50}$ values obtained were expressed in $\mu \mathrm{g} / \mathrm{mL}: 16 \pm 0.01$ and $9 \pm 0.04$ for EDB and DDB respectively. Ascorbic acid $(6.05 \pm 0.39 \mu \mathrm{g} / \mathrm{mL})$ was used as the reference molecule in Figure 1.

Table I. Phenolic contents and scavenging activity of the aqueous and ethanolic extracts of

\begin{tabular}{lcccc}
\hline $\begin{array}{c}\text { Parameters } \\
\text { Plants Extract }\end{array}$ & $\begin{array}{c}\text { Polyphenols total } \\
(\mathbf{m g} \text { GAE/g) }\end{array}$ & $\begin{array}{c}\text { Flavonoids } \\
(\mathbf{m g} \text { QE/g) }\end{array}$ & $\begin{array}{c}\mathbf{I C}_{\mathbf{5 0}}(\boldsymbol{\mu} \mathbf{g} / \mathbf{m L} \\
\text { of extract) }\end{array}$ & $\begin{array}{c}\text { \% Inhibition } \\
\text { At } \mathbf{0 . 5} \mathbf{~ m g} / \mathbf{m L}\end{array}$ \\
\hline EDB & $45.11 \pm 0.64^{\mathrm{a}}$ & $15.52 \pm 0.06^{\mathrm{a}}$ & $16 \pm 0.01^{\mathrm{b}}$ & $80.85 \pm 0.15$ \\
DDB & $39.84 \pm 0.18^{\mathrm{a}}$ & $15.64 \pm 0.03^{\mathrm{a}}$ & $9 \pm 0.04^{\mathrm{a}}$ & $85.29 \pm 0.15$ \\
\hline \hline Ascorbic acid & & & $6.05 \pm 0.02$ & $66.98 \pm 0.06$ \\
\hline
\end{tabular}

EDB/DDB: Hydroethanolic extract / Decocted of Disthemonanthus benthamianus Baill 


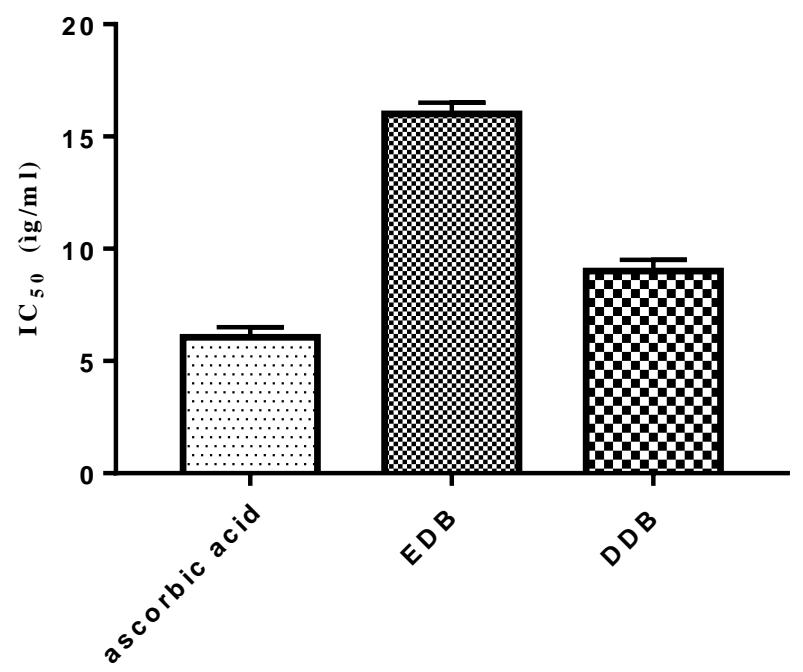

Figure 1: IC ${ }_{50}$ of ascorbic acid, DDB and EDB on DPPH discoloration.

\section{Reducing Power}

The results in the form of activity curves show that all the curves have increasing slope. The reducing power of the plant extracts, as indicated by the absorbance at $700 \mathrm{~nm}$, increased with increasing concentration of the samples (Figure 2). The reducing power of the plant extract versus plant extract concentration have a dose response relation. DDB shows higher reducing ability than EDB.

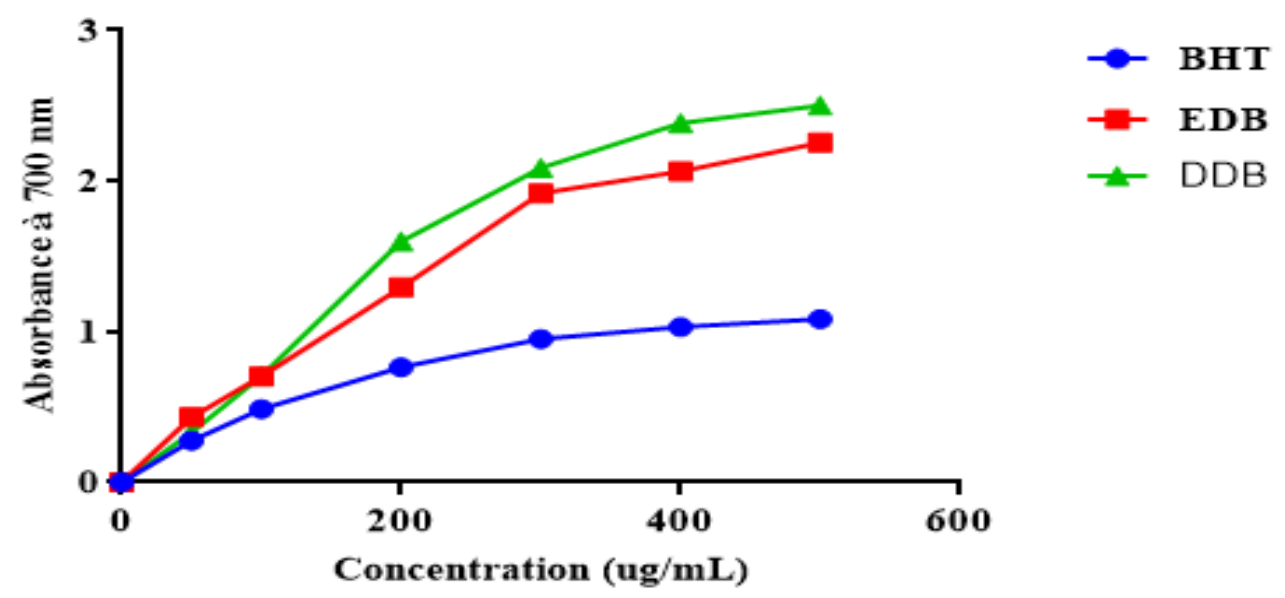

Figure 2. Reducing power of EDB, DDB and Butylated Hydroxytoluene 


\section{Aromatic Amino Acids Qualitative Research}

The test carried out on EDB and DDB allowed detecting the presence of aromatic amino acids in both extracts. The amino acids present were characterized by the yellow coloration of the reaction (Table II).

Table II. Aromatic amino-acids presence

\begin{tabular}{cc}
\hline Extract & Aromatic amino acids \\
\hline DDB & + \\
EDB & + \\
\hline
\end{tabular}

\section{Sickling Inhibitory Activity}

Figure 3 showed the microphotography of SS blood incubated in a tube containing $0.9 \% \mathrm{NaCl}$ and sodium meta-bisulfite $(2 \%, \mathrm{p} / \mathrm{v})$ without plant extract. In this figure, all the erythrocytes had a sickle shape two hours later. Figures 4 to 7 showed SS blood incubated in $0.9 \% \mathrm{NaCl}$ with sodium metabisulfite $(2 \%, \mathrm{p} / \mathrm{v})$ and plant extracts at 5 and $10 \mathrm{mg} / \mathrm{mL}$. EDB and DDB have displayed an ameliorating sickling effect. The sickle cell inhibition activity was determined and recorded in Table III; EDB $(87 \% \pm 1.33)$ had a higher inhibitory activity than DDB $(81.66 \% \pm 1.12)$ at $5 \mathrm{mg} / \mathrm{mL}$.

Table III. DDB and EDB sickling inhibitory activity

\begin{tabular}{lcc}
\hline Extracts & $\begin{array}{c}\text { Concentration: } \\
\mathbf{5 ~} \mathbf{~ g / m L}\end{array}$ & $\begin{array}{c}\text { Concentration: } \\
\mathbf{1 0} \mathbf{~ m g} / \mathbf{m L}\end{array}$ \\
\hline EDB & $87 \%$ & $73.39 \%$ \\
DDB & $81.66 \%$ & $72 \%$ \\
\hline \hline Phenylalanine & $67.33 \%$ & $83.65 \%$ \\
\hline
\end{tabular}

Figure 3. Morphology of sickle cell in the presence of $\mathrm{Na}_{2} \mathrm{~S}_{2} \mathrm{O}_{4} 2 \%$

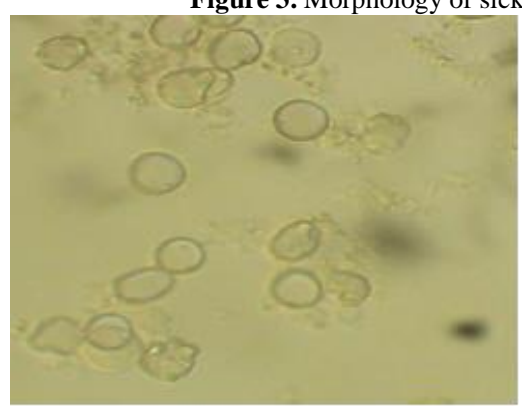

Figure 4 . Morphology of Sickle Cell Blood treated with $10 \mathrm{mg} / \mathrm{mL}$ of DDB

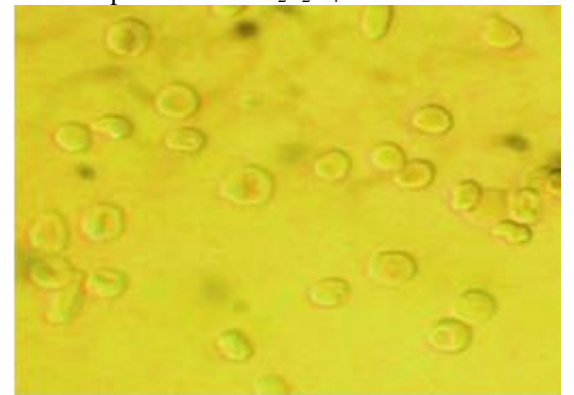

Figure 5 . Morphology of Sickle Cell Blood treated With $10 \mathrm{mg} / \mathrm{mL}$ of EDB 


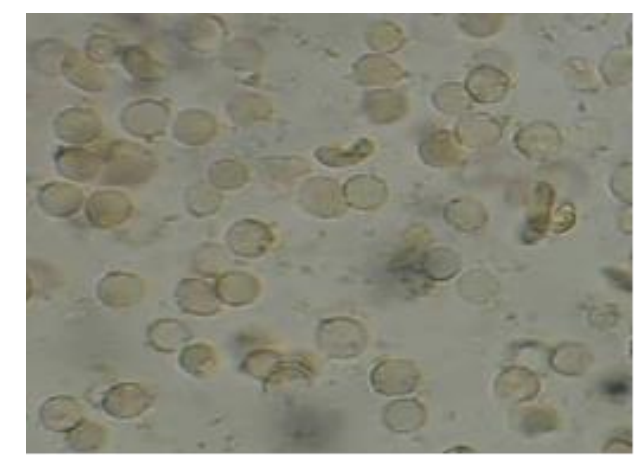

Figure 6 . Morphology of Sickle Cell Blood treated with $5 \mathrm{mg} / \mathrm{mL}$ of DDB

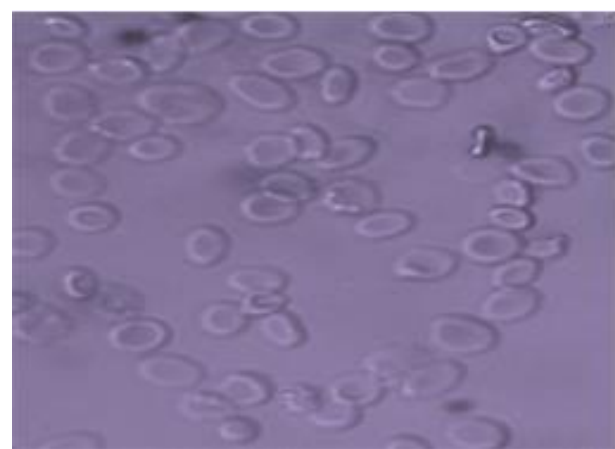

Figure 7 . Morphology of Sickle Cell Blood treated with $5 \mathrm{mg} / \mathrm{mL}$ of EDB

\section{Discussion}

The results of the total phenol assay were recorded in Table 1 . The polyphenol compounds contents in EDB and DDB were $45 \pm 0.01$ and 39.85 $\pm 0.18 \mathrm{mg} \mathrm{GAE} / \mathrm{g}$ of dry weight, respectively. Also, the total flavonoid contents were $15.88 \pm 0.06$ and $12.94 \pm 0.03 \mathrm{mg}$ GAE /g of dry weight, respectively. There was no significant difference between total EDB and DDB polyphenol levels. In addition, numerous other phytochemical examinations revealed the presence of tannins, flavonoids, alkaloids, steroids, and triterpenes in both extracts (Adebiyi et al., 2009; Bidié et al., 2011; Kehindé et al., 2012). The above-mentioned molecules could have some therapeutic effects in the treatment of diseases such as sickle cell (Longanga et al., 2000). The presence of secondary metabolites in EDB and DDB could explain their antioxidant activity. Indeed, the results of the antioxidant activity test showed that both extracts were active. The DPPH radical scavenging activity of EDB and DDB was indicated by their $\mathrm{IC}_{50}$ value in Table I and Figure 1. EDB and DDB IC 50 were $16 \pm 0.01$ and $9 \pm 0.04 \mu \mathrm{g} / \mathrm{mL}$ respectively. These two extracts had an antioxidant activity compared to ascorbic acid $(6.05 \pm 0.02 \mu \mathrm{g} / \mathrm{mL})$. Kouassi et al. (2013) study showed that the $\mathrm{IC}_{50}$ of the ethanolic and aqueous extracts were $10.87 \pm 0.18 \mu \mathrm{g} / \mathrm{mL}$ and $551.7 \pm 1.76 \mu \mathrm{g} / \mathrm{mL}$, respectively. These authors worked on the leaves of $D$. benthamianus, while the bark was used in this present study. The antioxidant activities of the plant would be related to their total phenolic compounds content. Indeed, functional groups in phenolic chemicals could produce an electron or proton to neutralize free radicals (Chen \& Ho, 1995).

According to Diatta et al. (2014), during oxidative stress in patients with sickle cell disease, lipid peroxidation products could produce oxidizing agents. These oxidative mediators could be responsible for the erythrocyte membrane structure damage. In a state of hypoxia, the oxidative stress occurring during sickle cell disease could increase methemoglobin level in red blood cells and weakened free radicals defense system (Nur et al., 2011). Also, this increased methemoglobin level would decrease hemoglobin oxygen 
affinity. The oxidized state of iron $\left(\mathrm{Fe}^{3+}\right)$ cannot bind the oxygen molecule (Sawadogo et al., 2017; Kitadi et al., 2015). The reducing power could allow EDB and DDB to change the iron from $\mathrm{Fe}^{3+}$ to $\mathrm{Fe}^{2+}$. This reduced state could increase haemoglobin oxygen affinity. Reducing power is an important antioxidant action of phenolic compounds (Nabavi et al., 2009a). EDB and DDB reducing power increased with increasing concentration (Figure 2). The reducing power test results showed that there was no significant difference between EDB (2.25 \pm 0.33$)$ and DDB $(2.50 \pm 0.38)$. This activity could be due to the presence of polyphenols compounds found in D. benthamianus extracts. Moreover, the work of Evenamede et al. (2017) highlighted a correlation between total phenol content and antiradical activity.

This antioxidant activity of $D$. benthamianus could be beneficial for the erythrocyte membrane. Indeed, the antioxidant activity of polyphenols is often exploited to prevent and treat diseases related to oxidative stress such as sickle cell disease. In fact, flavonoids (myricetin, quercetin, and rutin) are involved in inhibiting the damaging effects of reactive oxygen species produced during sickle cell disease (Railson et al., 2013). Some studies have shown that tannins, saponins, flavonoids, sterols, and ployterpenes have shown anti-inflammatory, antibacterial, antiviral, and anti-pain activities (Zouhri et al., 2016; Adeniyi et al., 2011; Bajerova et al., 2014; Gédéon et al., 2017; Akakpo-Akue et al., 2018). Indeed, these properties could neutralize free radicals by exchanging electrons or protons (Chen \& Ho, 1995). Polyphenols could block the free radical reaction chain by hydrogen transferring (Meir et al., 1995). They could also chelate metal ions (Ibrahim et al., 2017).

These current results also show the presence of aromatic amino acids EDB and DDB through the displayed yellow color. Many studies have shown that certain amino acids would stimulate the production of glutathione, significantly reduce the formation of sickle cell, and have a reversal effect on sickle cell shape (Gibson et al., 1998; N'Draman-Donou et al., 2015; Nur et al., 2012). The literature has shown that aromatic amino acids such as phenylalanine prevent polymerization of deoxygenated hemoglobin (Ogoda et al., 2002). The presence of these amino acids in our plant extracts could participate in the fight against sickle cell disease by having a polymerization inhibition activity (Tharaux, 2008).

The chemicals exposed in EDB and DDB could also be responsible for their sickling inhibitory activity. Indeed, morphological analysis of red blood cells incubated in $0.9 \% \mathrm{NaCl}$ and sodium meta-bisulfite $(2 \%, \mathrm{w} / \mathrm{v})$, without plant extracts showed two hours later in Figure 3, that all red blood cells had a sickle shape. The hypoxic environment created by the sodium meta-bisulfite $(2 \%, w / v)$ led to the formation of the sickle cells. This proved that the blood cells had the HbSS genotype and came from a homozygous sickle cell patient. 
In the presence of plant extracts, red blood cells treated with DDB showed in Figure $6(5 \mathrm{mg} / \mathrm{mL})$ and $4(10 \mathrm{mg} / \mathrm{mL})$ that all red blood cells have kept a rounded shape. Also, the erythrocytes treated with EDB had rounded and biconcave shape. Two hours after counting the sickle cells, the percentage of residual sickle cells compared to the negative control was determined. And the sickling inhibitory activity of EDB and DDB at 5 and $10 \mathrm{mg} / \mathrm{mL}$ was calculated in Table III. The result of the sickling inhibitory activity test showed that there was a dose-response relationship between plant extract concentration and inhibitory activity. Lower the concentration, better the activity. The sickling inhibitory activity of EDB at 5 and $10 \mathrm{mg} / \mathrm{mL}$ was $87 \%$ and $73.39 \%$ respectively. The same trend was observed for DDB. At 5 and 10 $\mathrm{mg} / \mathrm{mL}$, DDB extract had sickling inhibitory activity of $81.66 \%$ and $72 \%$ respectively. At $5 \mathrm{mg} / \mathrm{mL}$, the activities were superior to those of phenylalanine which was 83\%. At $10 \mathrm{mg} / \mathrm{mL}$, EDB (73.39\%) and DDB (72\%) activities were lower than phenylalanine (83\%). Higher concentrations of EDB and DDB may have reduced sickling inhibitory activity or a toxic effect on red blood cell HbSS. However, there was no significant difference between the sickling inhibitory activities of the ethanolic extract $(87.00 \%)$ and the decocted $(82.36 \%)$ at $5 \mathrm{mg} / \mathrm{mL}$.

The experimental results obtained during this in vitro study showed that both EDB and DDB extracts had an antifouling activity. This property could be due to the presence of polyphenols compounds in EDB and DDB.

\section{Conclusion}

The results of this study indicate that both the two Disthemonanthus benthamianus extracts are rich in phenolic compounds and flavonoids that have the ability to trap free radicals and reduce oxidants effect. The sickling inhibitory activity displayed by Disthemonanthus benthamianus extracts were correlated to phenolic compounds. These chemicals could be responsible for free radical scavenging and sickling inhibitory activity of $D$. benthamianus. Thus, these activities helps to explain the use of Disthemonanthus benthamianus to the traditional healers.

\section{Acknowledgements}

We would like to thank the officials and staff of the Hematology Unit of the Yopougon University Hospital, the Pasteur Institute of Cote d'Ivoire, not to mention those of the Pharmacognosy Laboratory of the UFR of Pharmaceutical and Biological Sciences of Felix Houphouet Boigny University in Cocody for their availability and assistance in carrying out the work. Also, we would also like to thank all the patients who have agreed to participate in this study. 


\section{Conflicts of Interest}

The authors declare no conflicts of interest regarding the publication of this paper.

\section{References:}

1. Adebiyi, A.O., Koekemoer, T., Adebiyi, A.P., Smith, N., Baxter, E., Naude, R.J. \& Van de Venter (2009). Antimicrobial and antioxidant activities of crude extracts of two Nigerian chewing sticks, Pharmaceutical Biology, 47:4, 320-327.

2. Adeniyi, B.A., Obasi, O.J. \& Lawal, T.O. (2011). In-vitro antifungal activity of Distemonanthus benthamianus stem. Int J Pharm Pharm Sci (3):52-56.

3. Akakpo-Akue, J., Kplé, T. K.M., Yapo-Crezoit, A., Fofié, Y., Kra, A. M., Tolo, D. A. \& N'Guessan, J.D. (2018). In vitro antisickling activity of the aqueous extract of a combination of three plants: "Jatropha grossypiifolia, Justicia secunda and Parquetina nigrescens from East Côte d'Ivoire." IOSR Journal of Pharmacy and Biological Sciences 13(6); 41-48.

4. Arruda, M. M., Mecabo, G., Rodrigues, C. A., Matsuda, S. S., Rabelo, I. B., \& Figueiredo, M. S. (2013). Antioxidant vitamins C and E supplementation increases markers of haemolysis in sickle cell anaemia patients: a randomized, double-blind, placebo-controlled trial. British Journal of Haematology, 160 (5), 688-700.

5. Bajerova, P., Adam, M., Bajer, T. \& Ventura, K. (2014). Comparaison de différentes techniques d'extraction et de dosage des antioxydants dans les plantes . J. Sep. Sci . 37, 835-844.

6. Béné, K., Camara, D., Fofie, Y., Kanga, Y., Yapi, A.B., Yapo, Y.C., Ambe, S.A. \& Zirihi, G.N. (2016). Étude ethnobotanique des plantes médicinales utilisées dans le Département de Transua, District du Zanzan (Côte d'Ivoire). Journal of Animal \&Plant Sciences. 27(2) :4230-4250.

7. Bidie, A.P., N'Guessan, B.B., Yapo, A.F., N'Guessan, J.D. \& Djaman, A.J. (2011). Activités antioxydantes de dix plantes medicinales de la pharmacopée ivoirienne. Sciences \& Nature 8 (1): 1 - 11.

8. Chavez, J.H., Leal, P.C., Yunes, R.A., Nunes, R.J., Barardi, C.R.M., Pinto, A.R., Simoes, C.M.O., Carlos, R. \& Zanetti, C.R. (2006). Evaluation of antiviral activity of phenolic compounds and derivatives against rabies virus. Veterinary Microbiology, 116: 53-59.

9. Chen, C.W. \& Ho, C.T. (1995). Antioxidant properties of polyphenols extracted from green tea and black tea. J Lipids, $2: 35-46$.

10. Chiabi, A. \& Haenggeli, C. (2004). New concepts in sickle cell anemia Clinics in Mother and Child Health 1(1). 
11. Daglia, M. (2012). Polyphenols as antimicrobial agents Current Opinion in Biotechnology.

12. Diatta, A., Cissé, F., Guèye, T. F., Diallo, F., Touré, F.A.O., Sarr, G. N., Lopez, S.P., Sall, N. D. \& Touré, M. (2014). Serum lipids and oxidized low density lipoprotein levels in sickle cell disease: Assessment and pathobiological significance African Journal of Biochemistry Research. Vol. 8(2), pp. 39-42.

13. Diomande, A., Yao, K., Sylla, Y., Tra, B.F.H., Bakayoko, A. \& Kone, M.W. (2018). Pouvoir antioxydant et teneurs en composés phénoliques de deux espèces du genre Albertisia: Albertisia cordifolia (Mangenot \& J. Miège) Forman et Albertisia scandens (Mangenot \& J. Miège) Forman (Menispermaceae). European Scientific Journal.14(30), 128.

14. Emmel, V.E. (1933). A red cell study of the érythrocytes in case of severe anaemia with elongated, sickle, and shaped red blood corpuscle. Archives of International Medicine, 7: 769-789.

15. Evenamede, K.S., Kpegba, K., Simalou, O., Boyode, P., Agbonon, A. \& Gbeassor, M. (2017). Etude comparative des activités antioxydantes d'extraits éthanoliques de feuilles, d'écorces et de racines de Cassia sieberiana. Int. J. Biol. Chem. Sci. 11(6): 2924-2935.

16. Fofana, S. (2004). Exploration biochimique sur le pouvoir immunogène de trois plantes en Côte d'Ivoire: Alstonia boonei (Apocynaceae), Mitragyna ciliata (Rubiaceae), Terminalia catappa (Combretaceae). Thèse de pharmacie, UFR de médecine, de pharmacie et d'odontostomatologie, Université de Bamako (Mali), 123 p.

17. Gedeon, B., Clement, I., Colette, M., Claudine, T., Emmanuel, L., Ruphin D., Mutwale, K., Kabamba, N., Theophile, M., Dorothee, T.P.M. \& Ngbolua, K.N. (2017). Assessment of Antisickling, Antioxidant and Antibacterial Activities of Some Congolese Taxa: Aframomum alboviolaceum (Ridley) K. Schum, Annona senegalensis Pers. and Mondia Whitei (Hook. f.) Skeels. American Journal of Laboratory Medicine. 2(4), 52-59.

18. Gibson, X.A., Shartava, A., McIntyre, J., Monteiro, C. A., Zhang, Y., Shah, A. \& Goodman, S. R. (1998). The efficacy of reducing agents or antioxidants in blocking the formation of dense cells and irreversibly sickled cells in vitro. Blood, 91(11), 4373-8.

19. Gonzalez, R., Ballester, I., Lopez-Posadas, R., Suarez, M.D., Zarzuelo, A., Martinez-Augustin, O. \& Sanchez, D.M.F. (2011). Effects of flavonoids and other polyphenols on inflammation. Crit Rev Food Sci Nutr, $51: 331-362$.

20. Hebbel, R.P., Morgan, W.T., Eaton, J.W., \& Hedlund, B.E. (1988). Accelerated autoxidation and heme loss due to instability of sickle 
hemoglobin. Proceedings of the National Academy of Sciences of the United States of America, 85(1), 237-41.

21. Ibrahim, A., Onyike, E., Nok, A.J. \& Umar, I.A. (2017). Combined Effect on Antioxidant Properties of Gymnema Sylvestre and Combretum Micranthum leaf extracts and the relationship to hypoglycemia. European Scientific Journal, 13(36) 266.

22. Kamanyi, A., Dongmo, A.B. \& Bopelet, M. (1995). Etude des proprietes hypotensives de l'extrait aqueux et une saponine total des feuilles de Musanga cecropioides (Cecropiaceae) chez le rat. Revue Medical. Pharmaceutique. Africaine, 9: 107-113.

23. Kehinde, T.K., Alli, S.O., Atayese, A.O., Ezeh, A.R. \& Alaga, T.O. (2012). Antibacterial Effect of Distemonanthus benthamianus Extract Against Some Oral Pathogens. International Journal of Applied Science and Technology, 2(2), 114.

24. Kitadi, J.M., Mazasa, P.P., Tshibangu, D.S.T., Memvanga, P.B., Ngbolua, K.N., Taba, N.K., Noki, P.V. \& Mpiana, P.T (2015). Antisickling and antioxidant activities of anthocyanins extracts from Dissotis brazzae Cogn (Melastomataceae), Journal of Advancement in Medical and Life Sciences.3(4):6.

25. Konkon, N.G., Adjoungoua, A.L., Manda, P., Simaga, D., N'Guessan, K. E. \& Koné, B.D. (2008). Toxicological and phytochemical screening study of MitragynaInermis(willd.) O ktze (Rubiaceae), antidiabetic plant. .J. Med. Plant Res. 2(10):279-284.

26. Kouassi, K., N'guessan, J.D., Méité, S., Yapi A., Yapi, H.F. \& Djaman, A.J. (2013). Antioxidant Activity and Phenolic Contents of the Leaves of Olax subscorpioidea and Distemonanthus benthamianus ; Research Journal of Pharmaceutical, Biological and Chemical Sciences 4(4), 1419.

27. Longanga, O.A., Vercruysse, A. \& Foriers, A. (2000). Contribution to the ethnobotanical, phytochemical and pharmacological studies of traditionally used medicinal plants in the treatment of dysentery and diarrhoea in Lomola area, Democratic Republic of Congo. Journal of Ethnopharmacology, 71: 411-423.

28. Meda, A., Lamien, C.E., Romito, M., Millogo, J. \& Nacoulma, O.G. (2005). Determination of total phenolic, flavonoid and proline contents in Burkina Faso honeys as well as well as their radical scavenging activity. Food. Chem.91:571-577.

29. Meir, S., Kanner, J., Akiri, B. \& Hadas, S.P. (1995). Determination and involvement of aqueous reducing compounds in oxidative defense systems of various senescing leaves. J Agric Food Chem 43: 18131819. 
30. Mpiana, P.T., Misakabu, F.M., Yuma, P.M., Tshibangu, D.S.T., Ngbolua, K.N., Mwanyishay, C.L. Misengabu, N.M., Gbolo, Z.B. \& Kayembe, J.S. (2014). Antisickling Activity and Physico-chemical Stability of Anthocyanin Extracts from Ipomoea Batatas Leaves. JLM. 2014;2(1):25-31.

31. Nabavi, S.M., Ebrahimzadeh, M.A., Nabavi, S.F., Fazelian, M. \& Eslami, B. (2009a). In vitro antioxidant and free radical scavenging activity of Diospyros lotus and Pyrus boissieriana growing in Iran. Pharmacognosy Magazine, 4(18): 123-127.

32. N'Draman-Donou, E., Fofié, Y., Adjambri, E., Mélèdje, M-F. \& Sawadogo, D. (2015). Caractérisation et évaluation in vitro de l'effet antifalcémiant des graines de Cajanus cajan (Fabacées) sur les drépanocytes à Abidjan Côte d'Ivoire.International Journal Biological and Chemical Sciences. 9(5): 2300-2308.

33. Nur, E., Biemond, B.J., Otten, H.M., Brandjes, D.P. \& Schnog, J.J. (2011). Oxidative stress in sickle cell disease; pathophysiology and potential implications for disease management. American Journal of Hematology, 86 pp 484-489.

34. Nur, E., Brandjes, D. P., Teerlink, T., Otten, H.M., Oude Elferink, R.P.J., Muskiet, F. \& Schnog, J.-J. B. (2012). N-acetylcysteine reduces oxidative stress in sickle cell patients. Annals of Hematology, 91(7), 1097-105.

35. Ogoda, O.J., Akubue, P.I. \& Okide, G.B. (2002). The kinetics of reversal of pre-sickled erythrocytes by the aqueous extract of Cajanus cajan seeds. Phytother Res., 16(8): 748-50.

36. Pandey, K.B. \& Rizvi, S.I. (2009). Plant polyphenols as dietary antioxidants in human health and disease. Oxid Med Cell Longev, 2: 270-278.

37. Parejo, I., Codina, C., Petraski, C. \& Kefalas, P. (2000). Evaluation of scavening activity assessed by co (II)/EDTA-induced luminal chemilunescence and DDPH (2,2-diphenyl-1-pycril hydrazyl) free radical assay. Journal of Pharmacology and. Toxicology Method, 44: 507-512.

38. Railson, H., Michel, F.O., Aline, E.F.F., Priscila, H., Aguinaldo, J.D.N. \& Maria, S.S.L. (2013). Protective effect of flavonoids against reactive oxygen species production in sickle cell anaemia patients treated with hydroxyurea. Revista Brasileira Hematolgia Hemoterterapia, 35(1): 52- 55.

39. Sawadogo, S., Sanou, S.D., Dabire, P., Belemtougri, G.R., Sawadogo Laya, J.L., Tanguy, S. \& Boucher, F. (2017). Activité antifalcémiante d'extraits de trois plantes médicinales du Bukina Faso : Jatropha 
curcas, Khaya senegalensis et Dichrostachys cinerea Int. J. Biol. Chem. Sci. 11(5).

40. Singleton, V.L., Orthofer, R., \& Lamuela Raventos, R.M. (1999). Analysis of total phenols and other oxydant substrates and antioxydants by means of Folin-ciocalteu reagent. Methods Enzymol. 299: 152-178.

41. Tharaux, PL. (2008). Une molécule utilisée dans l'hypertension artérielle pulmonaire pourrait aider à traiter la drépanocytose. Information presse < http : www.inserm.fr/fr/presse/communiques/ tt0000373/cp_drepanocytose_030408.pd> consulté le 17/03/09.

42. World Health Organization (2008). Fact sheet on traditional medicine. http://www. who.int/mediacentre/ factsheets/ fs 134/en/.

43. Yildirim, A., Mavi, A. \& Kara, A.A. (2001). Determination of antioxidant and antimicrobial activities of Rumex crispus L. extracts; Journal of Agricultural and Food Chemistry, 49: 411-420.

44. Zirihi, G., Kra, A.K.M. \& Guede-Guina, F. (2003). Evaluation de l'activité antifongique de Microglossa pyrifolia (Lamarck) O. Kantze (Asteracee) PYMI sur la croissance in Vitro de Candida albicans. Revue de Medecine et pharmacie Afrique. 17, 11-18.

45. Zouhri, A., Bousfiha, L. \& Aarab (2016). Evaluation of Antioxidant Properties, Anti-inflammatory and Photoprotective Effects of Lawsonia inermis Lipids, Phytothérapie. 